\title{
Suvremena obilježja funkcionalno-prostorne strukture Grada Krapine
}

\section{Jelena Lončar}

Sveučilište u Zagrebu, Prirodoslovno-matematički fakultet, Geografski odsjek, Hrvatska

e-mail:jloncar@geog.pmf.hr

\section{Ivan Sviben}

Sveučilište u Zagrebu, Prirodoslovno-matematički fakultet, Geografski odsjek, Hrvatska

e-mail:ivan.sviben@student.geog.pmf.hr

\begin{abstract}
SAŽETAK S obzirom na to da dosad nisu provedena istraživanja koja bi pojasnila i obradila problematiku prostorne, a time i funkcionalne strukture Grada Krapine, u ovom radu analizirat će se funkcionalna obilježja Grada Krapine s naglaskom na poslovne, odnosno upravne djelatnosti, na temelju dokumenata prostorno-planske dokumentacije, analize statističkih podataka i terenskog kartiranja. Na taj se način nastojala stvoriti baza podataka na temelju koje će se istražiti postojeća prostorna struktura Grada. Uz navedene metode dodatno je provedeno anketno istraživanje kako bi se ustanovila i analizirala razina zadovoljstva neposrednim životnim prostorom stanovnika koji žive na tom području, odnosno kako bi se moglo utvrditi koliko su stanovnici zadovoljni pojedinim aspektima života u Gradu Krapini. Pri tome je naglasak stavljen na dostupnost. U anketno istraživanje uključena su ukupno 132 stanovnika Grada Krapine. Rezultati istraživanja pokazali su kako su funkcije Grada Krapine koncentrirane najvećim dijelom u središnjem naselju, što je posljedica strukture analiziranih djelatnosti, ali i prirodnih obilježja koja ograničavaju prostorni razvoj, poput reljefnih karakteristika koje priječe disperziranje pojedinih djelatnosti u širi prostor, odnosno okolna naselja.
\end{abstract}

Ključne riječi: Grad Krapina, gradske funkcije, funkcionalna struktura, poslovne aktivnosti, prostorno širenje, anketno istraživanje, kvaliteta života. 


\section{Uvod}

Gradske funkcije poseban su interes proučavanja disciplina koje se bave prostorom, odnosno različitim procesima i aktivnostima koje se u njemu odvijaju. Takva istraživanja potiču ne samo znanstveni interesi već i praktične potrebe. Gradovi su mjesta koncentracije i centri polarizacije. Razumljivo je stoga da je bez poznavanja gradskih funkcija i njihova utjecaja, u ovom slučaju poslovnih, teško objasniti prostorne promjene i poduzeti planske akcije prostornog uređenja i regionalnog razvoja. Na specifičan razvoj Krapine velikim je dijelom utjecao i položaj u kotlini, pa su takve reljefne karakteristike umanjile predispozicije za razvoj Krapine uslijed smanjenih mogućnosti za fizičko širenje grada. Upravo je takav splet razvojnih specifičnosti glavni razlog pristupanja istraživanju suvremenih obilježja funkcionalne strukture Grada $^{1}$ Krapine te procesa i odnosa u prostoru koji proizlaze iz postojeće funkcionalne strukture i posljedično utječu na kvalitetu života lokalnog stanovništva.

Krapinsko-zagorska je, uz Ličko-senjsku, koja se najčešće percipira kao rijetko naseljeni prostor snažno pogođen dugogodišnjim negativnim demografskim procesima, jedina županija koja na svom prostornom obuhvatu nema grad snage regionalnog centra (Lukić, 2012.). Iako je jedna od najmnogoljudnijih i najgušće naseljenih županija, nije uspjela razviti nijedno veće naselje koje bi predstavljalo središte u funkcionalnom smislu. Stoga Grad Krapina, u nodalno-funkcionalnom smislu, gravitira Zagrebu.

Prema Popisu stanovništva iz 2011. godine u cijeloj Krapinsko-zagorskoj županiji živi 132.892 stanovnika, a u Gradu Krapini, koja je brojem stanovnika najveći grad Krapinsko-zagorske županije, 12.480 stanovnika (što je 9,4 \% ukupnog broja stanovnika Županije). U suvremenoj administrativno-teritorijalnoj podjeli Republike Hrvatske Grad čini jedinicu lokalne samouprave koja obuhvaća ukupno 23 naselja: Bobovje, Doliće, Donja Šemnica, Gornja Pačetina, Krapina, Lazi Krapinski, Lepajci, Mihaljekov Jarek, Podgora Krapinska, Polje Krapinsko, Pretkovec, Pristava Krapinska, Strahinje, Straža Krapinska, Škarićevo, Šušelj Brijeg, Tkalci, Trški Vrh, Velika Ves, Vidovec Krapinski, Vidovec Petrovski, Zagora i Žutnica (slika 1). Dakle osnovna je jedinica istraživanja u ovom radu Grad Krapina ukupne površine od $47,53 \mathrm{~km}^{2}$.

1 U radu će se riječ „grad“ s malim početnim slovom koristiti kada se odnosi na naselje Krapinu (odnosno kompaktno sagrađen prostor s cjelokupnim urbanim sadržajem; Vresk, 2002.) te $s$ velikim početnim slovom kada se odnosi na administrativni grad (jedinicu lokalne samouprave koja obuhvaća 23 naselja). 
Slika 1.

Geografski položaj Krapine

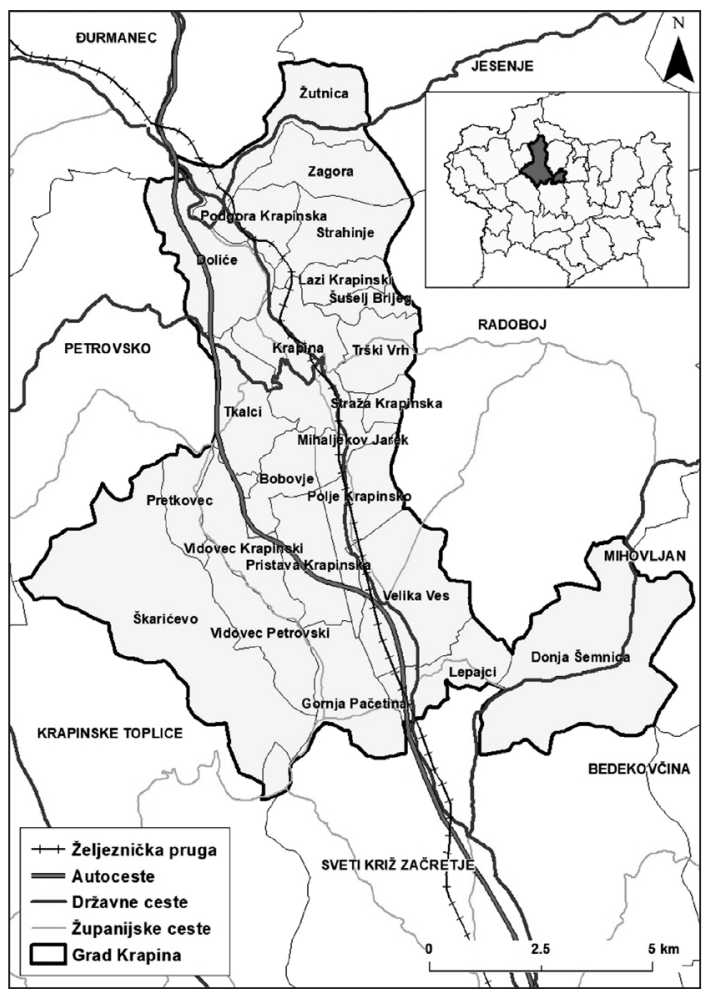

Izvor: izradili autori

Što se tiče zaposlenosti, koja je važna za razmatranje djelatnosti analiziranih u ovom istraživanju, prema podacima Popisa stanovništva Državnog zavoda za statistiku 2011. godine u Krapini je ukupno bilo 4.731 zaposlenih (16,6 \% zaposlenih u Županiji), dok je radno sposobnog stanovništva (15 - 64 godine) bilo 4.278. Udio dnevnih migranata u zaposlenom stanovništvu Grada Krapine iznosi 72 \%, premda samo jedno od ukupno 23 naselja ima manji udio dnevnih migranata od razine grada. To je, dakako, naselje Krapina, koje ima 44,8 \% dnevnih migranata u zaposlenom stanovništvu. Takvi pokazatelji upućuju kako Krapina nije veliki centar rada, naročito kada se uzme u obzir da je i danas administrativno središte Krapinsko-zagorske županije.

U cijeloj Krapinsko-zagorskoj županiji iste je godine bilo 28.468 zaposlenih. Kada se prouče podaci za Grad Krapinu, najviše je zaposlenih bilo u djelatnostima prerađivačke industrije (1.318 zaposlenih), trgovine na veliko i malo (585), javne uprave i obrane te obveznog socijalnog osiguranja (500). Nakon navedenih slijede djelatnosti građevinarstva (442), zdravstvene zaštite i socijalne skrbi (325), odnosno obrazovanja (300 zaposlenih). U svim ostalim djelatnostima bilo je zaposleno manje od 300 osoba. 
Utvrđivanje funkcionalno-prostorne strukture na području Grada Krapine doprinijet će stoga boljem razumijevanju cjelokupnih prostornih odnosa, što je osnova za pravilno planiranje budućeg razvoja Grada. Drugi je dio rada usmjeren na provođenje anketnog istraživanja s ciljem proširivanja primarne analize te utvrđivanja zadovoljstva stanovništva Grada dostupnošću pojedinih funkcija/usluga kako bi se utvrdilo zadovoljava li postojeća funkcionalna struktura potrebe lokalnog stanovništva.

\section{Teorijski okvir i prethodna istraživanja}

Funkcionalno-prostornu strukturu grada valja najprije promatrati s aspekta funkcija koje grad ima. Ona je jedna od komponenata složene prostorne strukture grada koja doživljava stalne promjene te se odražava u načinu iskorištavanja gradskog zemljišta, pa tako i u slučaju Grada Krapine. Njezini su elementi institucionalizirane proizvodne i uslužne djelatnosti razmještene u gradskom prostoru.

U Hrvatskoj je do sada objavljeno nekoliko istraživanja koja se odnose na problematiku funkcionalno-prostorne strukture, odnosno gradskih funkcija. Radovi se većinom odnose na proučavanje funkcionalnih karakteristika, tipova te odabranih funkcija u pojedinim gradovima.

Još je 1996. godine Milan Vresk objavio rad „Funkcionalna struktura i funkcionalna klasifikacija gradova u Hrvatskoj“, u kojem su obilježja funkcionalno-prostorne strukture hrvatskih gradova analizirana na temelju podataka o broju zaposlenih (stanovništva i dnevnih migranata) iz 1991. godine. Na temelju provedene analize, kojom su izračunati udjeli zaposlenih po svim djelatnostima, u radu su izdvojeni funkcionalni tipovi gradova u Hrvatskoj.

U kasnijim razdobljima objavljeni su radovi kao primjerice „Kulturne funkcije satelitskih gradova Zagreba“ autora Marijana Biruša, u kojem se analiziraju kulturne funkcije gradova Sesvete, Velika Gorica, Samobor i Zaprešić, dok autorica D. Seferagić 2005. godine piše rad „Piramidalna mreža gradova Hrvatske“. Osnovna je tema rada opremljenost infrastrukturom i dostupnost elemenata infrastrukturne opremljenosti u mreži odabranih gradova Hrvatske, a u tom se kontekstu analiziraju elementi društvene, tehničke i druge opremljenosti. U navedeno istraživanje uključena je i Krapina, za koju se, kao i ostale izabrane županijske centre, navodi da je slabije opremljena od glavnog grada i makroregionalnih središta, i to u elementima financijskih i drugih usluga, socijalne skrbi i zabave.

Zdenko Braičić u koautorstvu s E. Džihić piše „Utjecaj funkcija Siska i Petrinje na transformaciju i gravitacijsku usmjerenost prigradskog naselja Mošćenica“ (2015.). Rad se bavi analizom naselja Mošćenice pod utjecajem razvijenih funkcija Siska i Petrinje te funkcionalno-fizionomskom transformacijom navedenog naselja.

U svom istraživanju „Funkcija sjedišta županije i prometne veze kao čimbenici privlačnosti glavnih urbanih središta Hrvatske“ iz 2016. godine Zoran Klarić analizira radijus utjecaja najvažnijih hrvatskih gradova u odnosu na stanje iz 1992. godine. 
Ujedno se procjenjuje kako bi promjene mogle utjecati na mijenjanje teritorijalnog ustroja i pri tome dolazi do zaključka kako su županijski centri u odnosu na 1992. dobili na važnosti.

Od novijih istraživanja mogu se izdvojiti dva rada: „Analiza rekreacijske funkcije odabranih zelenih površina u Gradu Zagrebu - razlike u navikama posjetitelja“ autora Opačić, V. T., Gašparović, S. i Dolenc, N. te „Primjena metode obuhvata područja za određivanje dostupnosti poštanskih ureda: primjer Bjelovarsko-bilogorske županije, autora Mostarac, K. i Felatar, P.

Prvi spomenuti rad odnosi se na istraživanje triju rekreacijskih točaka u Gradu Zagrebu te putem anketiranja na utvrđivanje navika posjetitelja. Na temelju utvrđenih razlika izdvojeni su tipovi zelenih površina u gradu te je pobliže razmotrena njihova rekreacijska funkcija. Drugi navedeni rad proučava dostupnost poštanskih ureda s ciljem utvrđivanja obuhvata poštanske mreže.

U stranoj literaturi koja se također bavi funkcionalnom strukturom gradova može se izdvojiti rad koji je u Sloveniji objavio Mirko Pak „Problematic of the functional structure of Slovenian cities"iz 2004. godine.

Knjigu koja obrađuje funkcije i funkcionalnu hijerarhiju gradova u Poljskoj (Central Functions and Functional Hiarachy of Cities and Towns in Poland) objavio je autor Dariusz Sokolowski (2006.).

Autori Živanović i Tošić bavili su se istraživanjem funkcionalnog utjecaja Beograda na njegovo izvanadministrativno područje, odnosno određivanjem granica njegova funkcionalnog područja prema određenim kriterijima (The need of harmonising the administrative and functional metropolitan area: The case of Belgrade, 2016). Treba spomenuti i rad iz 2018. godine u kojem je obrađena tema utjecaja urbanih sadržaja na kvalitetu života u gradu Banskoj Bystrici u Slovačkoj (Urban facilities in the quality of life research: A case study of Banska Bystrica city (Central Slovakia)). Ono je provedeno na temelju terenskog rada, a usmjereno je na jedan od ukupno 13 urbanih distrikata Banske Bystrice, čiji je razvoj, kao i u slučaju Krapine, prostorno ograničen nepovoljnim reljefom tj. smještajem u Zvolenskoj kotlini. Navedeni je problem posljedično utjecao na razvoj i razmještaj urbanih sadržaja u gradu.

U okviru primijenjenog istraživanja ESPON-a objavljeno je i izvješće kojem su tematika mali gradovi, točnije „Small and Medium sized towns in their functional territorial context" (2013.).

U analizi kvalitete života na razini gradova, odnosno gradskih naselja korištena je literatura autora različitih znanstvenih disciplina. U okviru geografskih istraživanja najviše je radova o kvaliteti života pisala Slavuj Borčić, kako općenito o razvoju geografskih interesa istraživanja za navedenu tematiku (2017.) tako i o određivanju objektivnih i subjektivnih indeksa kvalitete života (2012., 2014.) te konkretno o kvaliteti života u gradu Rijeci i urbanim susjedstvima (2011., 2012.). 
Autori Mirošević. L. i Jolić, J. proučavali su objektivne i subjektivne pokazatelje kvalitete životnog prostora u Požegi (2015.), dok su o kvaliteti života u ruralnim krajevima (primjer Gornje Rijeke) 2016. godine pisale Klempić Bogadi i suradnice.

Od socioloških istraživanja ističe se nekoliko radova poput „Kvaliteta stanovanja u mreži naselja Hrvatske“ autorice Svirčić Gotovac, pri čemu je predmet istraživanja bio ispitati kvalitetu života u mreži naselja na razini cijele Hrvatske, i to preko elemenata stanovanja, opremljenosti kućanstava te opremljenosti neposredne okoline ili susjedstva u naseljima. Treba spomenuti i rad „Prehrana i zdravlje kao elementi kvalitete života u mreži naselja Hrvatske“ autorica Svirčić Gotovac i Zlatar (2007.) te knjigu istih urednica pod nazivom „Kvaliteta života u novostambenim naseljima i lokacijama u zagrebačkoj mreži naselja“iz 2015. godine.

\section{Metode istraživanja}

Glavna metoda koja je korištena za prikupljanje prostornih podataka bila je terensko kartiranje. Njime su utvrđene lokacije poslovnih i upravnih djelatnosti na prostoru Grada Krapine, na temelju čega je stvorena prostorna baza podataka koja je kasnije služila za utvrđivanje i analizu funkcionalno-prostorne strukture.

Prema dostupnim podacima, na prostoru Krapinsko-zagorske županije registrirano je i aktivno 4.568 pravnih osoba, od čega je aktivnih 2.851 (ili 1,9\% u R. Hrvatskoj). Među 32 jedinicama lokalne samouprave Krapinsko-zagorske županije prema broju poduzetnika izdvajaju se Krapina (311) i Zabok (254). Kad se analiziraju zaposleni, dominiraju poduzetnici Krapine s 3.481 zaposlenim, Zaboka s 2.562 zaposlena te Huma na Sutli s 2.023 zaposlena. S obzirom na veličinu ostvarenog prihoda, osim poduzetnika u Humu na Sutli (1,95 milijardi kuna), koji su u 2018. godini ostvarili najveći ukupan prihod, izdvajaju se i poduzetnici u Krapini (1,68 milijardi kuna) i Zaboku (1,58 milijardi kuna) (FINA, www.fina.hr).

U Krapini je u okviru ovog istraživanja zabilježen 431 objekt s poslovnom i upravnom funkcijom te još 25 napuštenih objekata, što je bitno radi utvrđivanja poslovnih djelatnosti na kojima se temelji funkcionalna usmjerenost tog prostora.

Kartirani objekti poslovnih i upravnih funkcija u Krapini podijeljeni su u nekoliko skupina, a to su: trgovina za kratkoročne potrebe, trgovina za dugoročne potrebe, ugostiteljski objekti, profesionalne usluge, obrti i osobne usluge, financijsko poslovanje, proizvodnja, turistički i smještajni objekti, komunalne usluge, tijela državne uprave, obrazovanje i kultura, zdravstvene ustanove, napušteni objekti te ostali objekti.

Skupina „trgovina za kratkoročne potrebe“ uključuje trgovine mješovitom robom (npr. Konzum), sve specijalizirane trgovine hranom i/ili pićem, cvjećarnice, kioske i sl. Skupina „trgovine za dugoročne potrebe “ uključuje trgovine s odjećom i obućom, namještajem, suvenirima, tehničkom robom, papirnice, knjižare, ljekarne i sl. Skupina „obrti i osobne usluge" uključuje postolare, razne mehaničarske radionice, krojače, kozmetičke salone, frizere i sl., dok „financijsko poslovanje“ uključuje ban- 
ke i bankomate, osiguravajuća društva te poštu. Pod „profesionalnim uslugama“ podrazumijevaju se javni bilježnici, odvjetnički uredi, privatne liječničke i stomatološke ordinacije, optike, konzultantske tvrtke, softverske tvrtke i sl. U skupini „ostali objekti“ pridruženi su objekti koji po funkcionalnosti nisu mogli biti pridruženi ni jednoj navedenoj skupini. ${ }^{2}$ Nazivi ostalih skupina jasno upućuju na to koji su objekti uključeni unutar njih, pa ih zato ne treba posebno objašnjavati. Terensko je kartiranje provedeno od 12. do 24. kolovoza 2018. godine, a u još trima terenskim izlascima (12. i 13. studenog te 16. prosinca 2018.) dodatno su utvrđeni prostorni odnosi te provjereni pojedini kartirani objekti. Prostorna analiza i vizualizacija kartiranih objekata obavljena je u programu ArcGIS (verzija 10.1.).

U radu su također analizirani podaci prikupljeni iz Popisa stanovništva, kućanstava i stanova 2011. godine. Za razumijevanje planiranja funkcionalne strukture kroz povijest korišten je Generalni urbanistički plan Općine Krapina (1988.), čiji su tekstualni i grafički dijelovi prikupljeni u Upravnom odjelu za prostorno uređenje, gradnju, zaštitu okoliša i komunalno gospodarstvo Grada Krapine.

Druga metoda koja je korištena u radu metoda je anketnog istraživanja. Statistička obrada anketnog upitnika temeljila se na prikazima apsolutnih vrijednosti, izračunu postotaka i aritmetičkih sredina ${ }^{3}$. Anketiranje se provodilo u dvama navratima - početkom listopada 2018. godine (8. - 13. listopad 2018.) i studenog (2. - 5. studeni 2018.). Anketni upitnik sastojao se od 18 pitanja zatvorenog tipa, a ispunila su ga ukupno 132 stanovnika Grada Krapine. Od ukupnog broja ispitanika njih 72 bilo je iz naselja Krapine, a 60 iz ostalih naselja. Anketno istraživanje provodilo se u naseljima u kojima je kartirano deset i više objekata jer kao takva na istraživanom prostoru predstavljaju funkcionalno jača naselja kojima gravitira stanovništvo ostalih (funkcionalno slabijih) naselja ${ }^{4}$. Uvjeti za sudjelovanje u anketiranju bili su da ispitanici žive u Gradu Krapini te da su punoljetni.

\section{Obilježja funkcionalno-prostorne strukture Grada Krapine}

U gradu se obično ističu zone stanovanja, rada, rekreacije i poslovne zone (koje se pak mogu dijeliti na trgovačke, financijske, ugostiteljske i dr.) (Vresk, 2002.). Gradove općenito treba promatrati kao mjesta rada i stanovanja. Funkcionalno-prostorna struktura u cjelini se može utvrditi kartiranjem kategorija iskorištavanja, odnosno namjene površina za pojedine funkcije. Tu su vrlo bitna fizičko-geografska obilježja prostora koji se proučava.

2 Terenskim kartiranjem ukupno su evidentirana četiri objekta iz skupine „ostali objekti“, a to su tri sportske kladionice i jedna kockarnica. Sva se četiri objekata nalaze u gradskom centru.

3 Aritmetičke sredine računale su se za prikazivanje zadovoljstva odabranim aspektima života, koje se u većini slučajeva temeljilo na subjektivnoj procjeni zadovoljstva dostupnošću pojedinih gradskih funkcija anketiranom stanovništvu grada (npr. zadovoljstvo dostupnošću objekata financijskog poslovanja).

4 To su Krapina, Velika Ves, Mihaljekov Jarek, Bobovje, Polje Krapinsko, Lepajci, Podgora Krapinska i Doliće. 
Na višim je nadmorskim visinama teže organizirati poslovanje, naročito proizvodnih objekata, osim ako nisu primarno vezani za iskorištavanje nekih prirodnih resursa koji su karakteristični za više nadmorske visine. Osim toga, lociranje poslovnih objekata na višim nadmorskim visinama u pravilu smanjuje dostupnost za potencijalne korisnike. Takav smještaj ujedno poskupljuje i povećava energiju potrebnu za prijevoz robe, što je nekompatibilno s energetski učinkovitim poslovanjem te generalno otežava njegovo odvijanje (Le Nechet, 2012.).

Reljefna obilježja prostora Grada Krapine i nepostojanja većih naselja, osim Krapine u kojoj je koncentrirano gotovo $70 \%$ svih poslovnih i upravnih funkcija, posljedično su utjecala na to da je na najnižim prostorima do 200 metara nadmorske visine locirano čak 93,4\% kartiranih objekata (slika 2). Svi ostali objekti, ukupno njih 30 (6,6 \%), nalaze se u prostorima između 201 i 300 metara nadmorske visine.

Slika 2.

Hipsometrijska karta administrativnog područja Grada Krapine

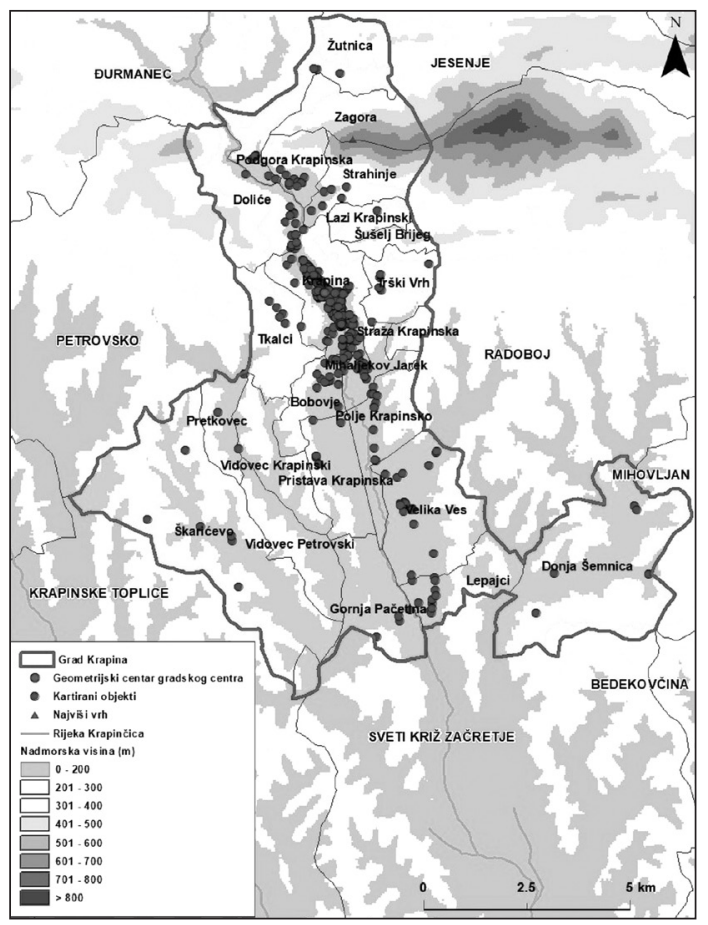

Izvor: izradili autori

Takvi podaci također nisu iznenađujući jer se današnje gradsko središte nalazi u dolini rijeke Krapinčice. S obzirom na lokaciju gradskog centra u dolini Krapinčice, ne iznenađuje kako su današnji poslovni objekti koji se nalaze izvan gradskog središta prisutni upravo u najnižim dijelovima istraživanog prostora. U tim je dijelovima također najveća gustoća naseljenosti, što je bitno u planiranju lokacije poslovnih objekata zbog blizine potencijalnih korisnika. 
Drugi izuzetno važan faktor lokacije poslovanja na prostoru Krapine udaljenost je od gradskog centra. Naime, upravo su fizičko-geografska obilježja determinirala širu lokaciju koja se kroz određeno vremensko razdoblje razvila kao gradsko središte, odnosno koja je postala ishodište prostornog širenja Krapine. Za oblikovanje funkcionalno-prostorne strukture posebno se naglašava značenje vrijednosti gradskog zemljišta. Skuplje zemljište, odnosno lokacije u središtu grada, imaju one funkcije koje na malim površinama imaju veliku učinkovitost poslovanja. Od središta prema rubu grada vrijednosti se zemljišta u pravilu smanjuju, pa se zbog toga smanjuje intenzitet iskorištavanja. Bez obzira na to što takav teoretski pristup pretpostavlja homogena obilježja grada, njime se, s izvjesnim modifikacijama zbog utjecaja nekih drugih faktora, može objasniti način korištenja zemljišta, odnosno razvoj funkcionalno-prostorne strukture grada (Vresk, 1986.).

I ovdje se realiziraju te teorijske pretpostavke, odnosno broj kartiranih objekata smanjuje se s udaljavanjem od gradskog centra (slika 3). Točka iz koje je prikazana udaljenost od geometrijskog centra izračunata je nakon izdvajanja gradskog centra.

Slika 3.

Udaljenost kartiranih objekta od geometrijskog centra Krapine

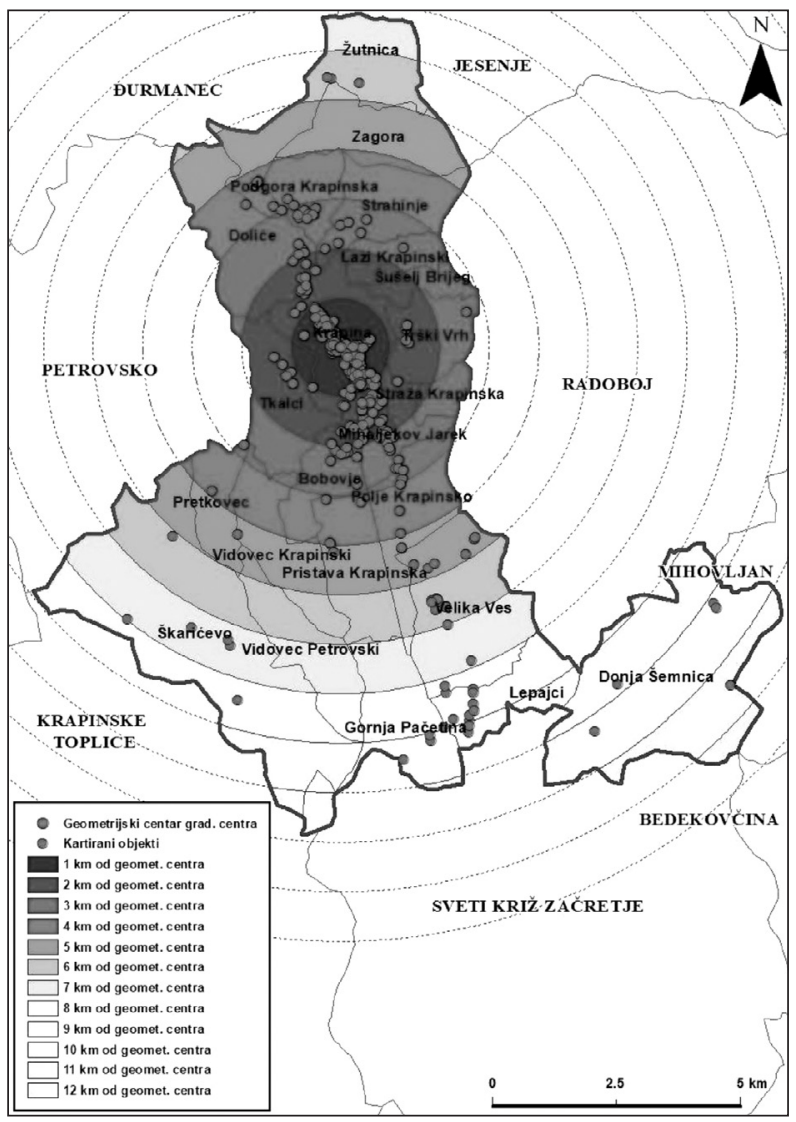


U izdvojenom gradskom centru najveća je koncentracija poslovnih i upravnih funkcija u Gradu Krapini, stoga je točka koja je izračunata kao geometrijski centar izdvojenog gradskog centra ${ }^{5}$ uzeta kao ishodišna. ${ }^{6}$ Unutar jednog kilometra udaljenosti od geometrijskog centra nalaze se čak 253 kartirana objekta, odnosno 58,7 \% svih objekata s poslovnom ili upravnom funkcijom.

Pravilnost u padu broja objekata s poslovnim i/ili upravnim funkcijama prisutna je do prostora na udaljenosti između pet i šest kilometara od geometrijskog središta Krapine. Na udaljenosti između šest i sedam kilometara od geometrijskog središta ponovno pada broj objekata s poslovnim i upravnim funkcijama. Na tom je dijelu prisutno samo pet objekata s poslovnim i/ili upravnim funkcijama. Na prostoru izmedu sedam i osam kilometara udaljenosti od gradskog centra broj objekata s poslovnim i/ili upravnim funkcijama ponovno raste, i to više nego dvostruko (11). Razlog je tome što taj prostor obuhvaća dijelove funkcionalno jačih naselja Velike Vesi i Lepajca. Veći broj objekata u tim naseljima posljedica je također boljeg prometnog položaja u odnosu na ostala udaljenija naselja (izlaz s autoceste Zagreb Macelj u Velikoj Vesi i položaj na glavnoj pristupnoj cesti prema Krapini ${ }^{7}$ ) i blizine poduzetničke zone ${ }^{8}$. Nakon te samo naizgled prostorne nelogičnosti nastavlja se pravilno smanjivanje broja kartiranih objekata udaljavanjem od geometrijskog centra Grada Krapine.

\section{Analiza funkcionalne strukture}

Iz prostornog razmještaja kartiranih skupina objekata jasno je uočljiva funkcionalna dominantnost naselja Krapine u odnosu na ostala 22 naselja, čime je dodatno naglašena razlika urbanog u odnosu na ruralni prostor. U naselju Krapini kartirano je 318 objekata od ukupno 456, odnosno čak 69,7 \% svih objekata. Ako idealizirano pretpostavimo da je u ostalim 22 naseljima prisutan jednak broj kartiranih objekata, odnosno da su ostala naselja jednako funkcionalno opremljena, dobit ćemo rezultat da se prosječno u ostalim naseljima nalazi samo između šest i sedam objekata s poslovnim i/ili upravnim funkcijama. To je, dakako, samo idealizirani statistički scenarij, koji ne mora odgovarati prostornoj stvarnosti. U njoj su određena naselja funkcionalno u potpunosti neopremljena te samim time za stanovništvo neatraktivna.

5 Kasnije će se u radu koristiti samo termin „geometrijski centar“.

${ }^{6}$ Način izdvajanja gradskog centra analizirat će se kasnije u radu na temelju analize terenskog kartiranja objekata s poslovnom i upravnom funkcijom.

${ }^{7}$ Posljedično je utjecalo na lociranje nešto većeg broja ugostiteljskih i smještajnih objekata.

8 Poduzetnička zona bitan je faktor lociranja nešto većeg broja trgovina i jednog proizvodnog pogona. 
Slika 4.

Prostorni razmještaj poslovnih objekata

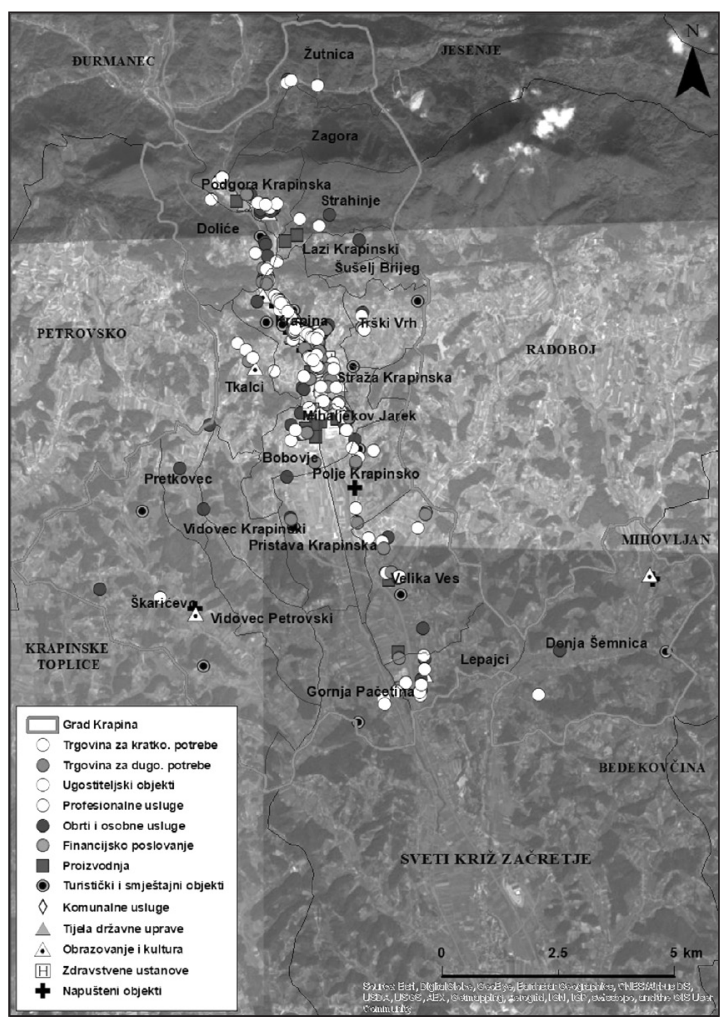

Izvor: izradili autori

Neravnoteža u prostornom razmještaju kartiranih objekata još je izraženija ako broj kartiranih objekata prikažemo po jedinici površine. S obzirom na to da površina naselja Krapine iznosi $2,55 \mathrm{~km}^{2}$, a Grada Krapine $47,53 \mathrm{~km}^{2}$, tim načinom prikazivanja prostornog razmještaja kartiranih objekata dobit ćemo rezultat da je u naselju Krapini na $1 \mathrm{~km}^{2}$ prisutno približno 120 objekata, dok su u prostorima izvan naselja Krapine, tj. prostorima ostalih naselja na istoj površini, prisutna samo tri.

Radi pojednostavljenja analize i bolje preglednosti kartiranog sadržaja promatrani prostor Grada Krapine podijeljen je na tri dijela - sjeverni, središnji i južni dio, a zasebno je također analiziran i gradski centar.

Sjeverni dio istraživanog prostora obuhvaća naselja Žutnicu, Zagoru, Podgoru Krapinsku, Doliće, Strahinje i Laze Krapinske. Ukupna površina tog dijela istraživanog prostora iznosi 10,35 km² (21,8 \% ukupne površine Grada Krapine). U tim je naseljima ukupno evidentirano 35 poslovnih i upravnih objekata te jedan napušteni objekt. 
Slika 5.

Prostorni razmještaj objekata na sjevernom dijelu istraživanog prostora

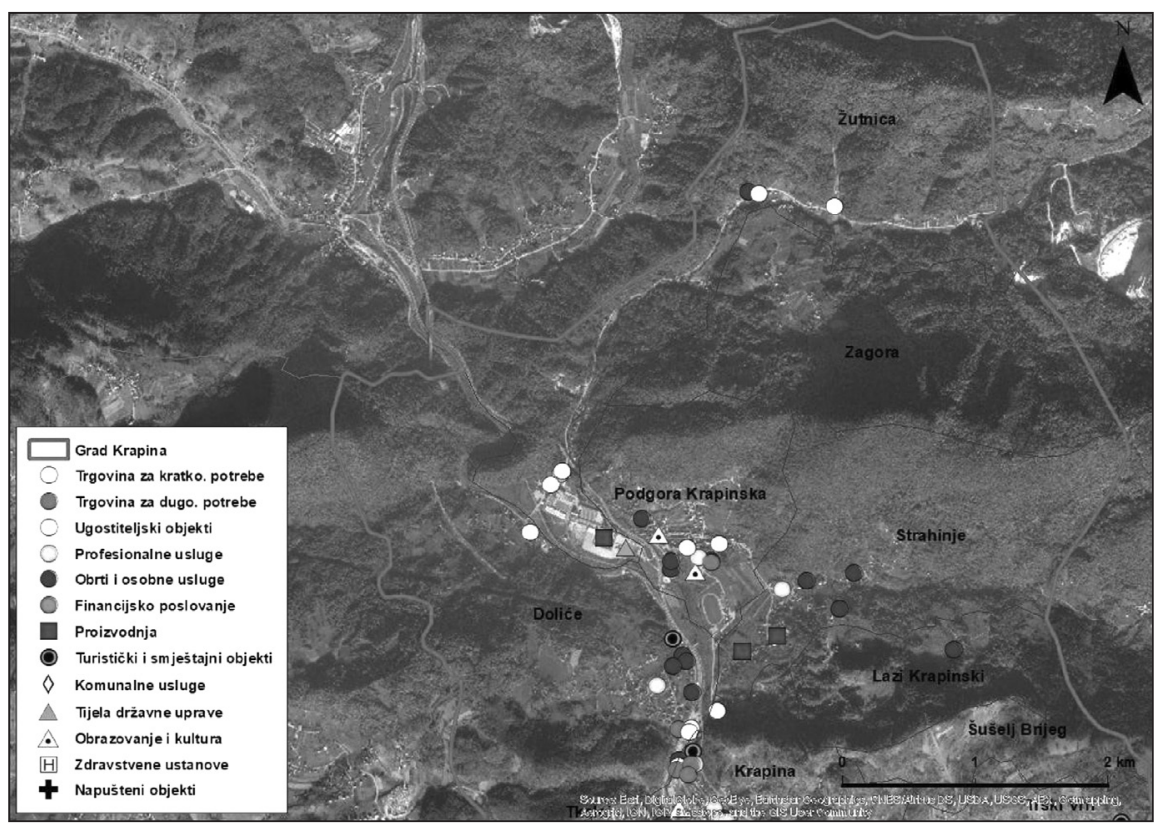

Izvor: izradili autori

Razlog manjeg broja kartiranih objekata na tome prostoru jesu velike površine pod šumom te smještaj na višim nadmorskim visinama, prvenstveno na istočnom, a manjim dijelom i na zapadnom dijelu izdvojenog istraživanog prostora. To je glavni razlog funkcionalne neopremljenosti i posljedično malog broja stanovnika u naseljima Zagori i Lazima Krapinskim. Naselja u kojima je utvrđeno najviše objekata s poslovnom i upravnom funkcijom su Dolice (10), Podgora Krapinska (9) i Žutnica $(8+$ jedan napušten objekt). U tim se naseljima nalazi čak $77,8 \%$ objekata na tom dijelu istraživanog prostora.

S obzirom na vrstu kartiranih objekta, odnosno njihove funkcije, može se ustvrditi kako sjeverni dio Krapine ima dosta izraženu industrijsku, odnosno proizvodnu i strijalizacije Krapine, kada je ovdje formirana stara industrijska zona zbog blizine ugljenokopa i kamenoloma u današnjem naselju Doliće, koji su ovdje radili sve do 1972. godina (Enciklopedija Hrvatskog zagorja, 2017.). Nakon zatvaranja na tom su se prostoru formirale nove individualne stambene zone te tada započinje proces fizičkog srastanja današnjeg centra Krapine s naseljima Doliće, Strahinje, Podgora Krapinska i Žutnica.

Među kartiranim objektima na tom prostoru brojem dominiraju „obrti i osobne usluge“. Od ukupno 13 objekata iz navedene skupine najviše (4) ih se nalazi u naseljima Doliće i Podgora Krapinska, tri u naselju Strahinje te po jedan u Žutnici i Lazima Krapinskim. Specifičnost je tog prostora što se u njemu nalazi jedino naselje, osim naselja Krapina, 
u kojem postoje i dječji vrtić i osnovna škola, a to je Podgora Krapinska. Postojanje obrazovne funkcije izuzetno je važno za kvalitetu Života stanovništva toga i obližnjih naselja. Važno je također naglasiti kako se u naselju Žutnici nalazi jedini objekt tijela državne uprave koji je lociran izvan gradskog naselja, a to je Carinska ispostava Krapina. S obzirom na blizinu graničnih prijelaza sa Slovenijom (Macelj, Lupinjak), utjecaj tog objekta vrlo je važan za zadovoljavanje potreba gospodarskih subjekata koji sudjeluju u carinskom poslovanju. Druga su najbrojnija skupina „ugostiteljski objekti“, kojih je ukupno šest. Svi su ugostiteljski objekti na tom prostoru kafići te su prisutni također samo u funkcionalno najopremljenijim naseljima: Dolicee, Podgora Krapinska i Žutnica. Trgovačke funkcije prisutne su u trima funkcionalno najopremljenijim naseljima, što je glavni poticaj dnevnom migriranju stanovništva. Općenito, pravilnost koncentracije objekata na tom dijelu vezana je za glavne prometnice i ulice pojedinih naselja. U njima je dominantna stambena funkcija, dok su poslovne funkcije, naročito obrti (autoservisi, razne mehaničarske radionice, frizerski i saloni ljepote i sl.) te manjim dijelom profesionalne usluge, često locirane unutar ili u dvorištu privatnih kuća.

Središnji dio istraživanog prostora obuhvaća gradsko naselje Krapinu te naselja Tkalce, Trški Vrh, Bobovje, Mihaljekov Jarek, Stražu Krapinsku i Šušelj Brijeg. Ukupna površina tog dijela iznosi samo $8,4 \mathrm{~km}^{2}$ (17,7 \% ukupne površine Grada Krapine), ali na njemu živi više od polovice stanovnika Grada Krapine (6.323 ili 50,1 \%). Logično je stoga kako je od triju izdvojenih dijelova upravo to prostor na kojem je evidentirano najviše poslovnih i uslužnih objekata (337), uz 21 napušteni objekt. U dvama naseljima nije evidentiran ni jedan objekt s poslovnom i/ili upravnom funkcijom. To su površinom i brojem stanovnika dva najmanja naselja Grada Krapine - Šušelj Brijeg i Straža Krapinska.

Slika 6.

Prostorni razmještaj objekata na središnjem dijelu istraživanog prostora

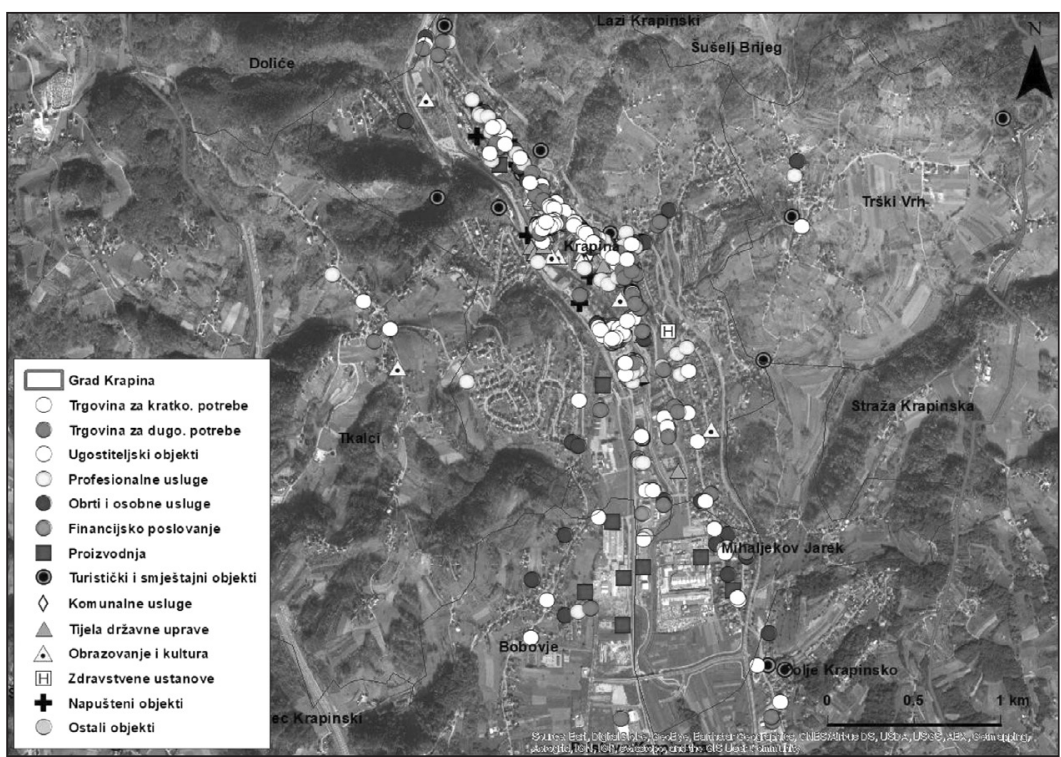


Najveća koncentracija stanovništva na tom prostoru posljedično je utjecala na lociranje sedam obrazovnih i jedine zdravstvene institucije, komunalnog poduzeća koje pruža komunalne usluge na području bivše općine Krapina te gotovo svih objekata financijskog poslovanja i tijela državne uprave.

Među kartiranim objektima najviše je objekata iz skupine „profesionalne usluge“ (69), a slijede skupine „trgovina za dugoročne potrebe“ (50), zatim „trgovina za kratkoročne potrebe“ (44), „obrti i osobne usluge“ (43) i „ugostiteljski objekti“ (38). Navedene skupine pripadaju tercijarnim djelatnostima, koje se nastoje locirati na mjestima najveće dostupnosti, odnosno u najfrekventnijim ulicama, stoga će se njihova struktura i prostorni razmještaj detaljnije analizirati unutar potpoglavlja Gradski centar. Tu je također dosta izražena proizvodna funkcija jer postoji devet proizvodnih pogona, od kojih je najviše (njih četiri) locirano u naselju Bobovje, tri su Mihaljekovu Jarku i dva u Krapini. Najpoznatiji proizvodni pogon na tom dijelu istraživanog prostora tvornica je „Jedinstvo d.o.o." u Mihaljekovu Jarku.

Najviše je objekata kartirano u Ulici Frana Galovića, njih 57. Navedena ulica ne pripada izdvojenom gradskom centru, a prema strukturi najviše je objekata u skupini „profesionalne usluge“ (28,1\%). Sljedeća najbrojnija skupina $(21,1 \%)$ iz kategorije je „financijsko poslovanje“, a slijede „tijela državne uprave“ (17,5\%). Od ostalih najviše je napuštenih objekata (8,8 \%), a u navedenoj ulici također su „ugostiteljski objekti“, „trgovine za kratkoročne potrebe“, „obrti i osobne usluge“, „trgovine za dugoročne potrebe“, „proizvodnja“ i „turistički i smještajni objekti“. Zbog navedenog je jasno da ta ulica ima izrazito naglašenu poslovnu funkciju. Morfologija gradskog centra Krapine definirana je prije više od pola stoljeća, te u njemu gotovo da i nema slobodnog prostora. Navedena ulica također je vrlo važna u prometnom smislu za Krapinu jer rasterećuje promet kroz centar grada te ujedno doprinosi povećanju prometne dostupnosti poduzetničke zone.

Gradski centar mjesto je gdje funkcije i urbanističke vrijednosti dostižu svoj maksimalni intenzitet (Maretić, 1996.). Osim najintenzivnije koncentracije centralnih funkcija grada, neka su obilježja gradskih središta: velika gustoća izgrađenosti i urbanističkih vrijednosti, velika gustoća zaposlenosti i stanovanja, najveća vrijednost i iskorištenost gradskog zemljišta, veliki broj poslovnih ureda i specijaliziranih prodavaonica, prisutnost značajnih povijesnih građevina, sjecište linija javnog prometa, mjesto susreta građana i posjetitelja i sl. (Maretić, 1996.). Vodeći se prostornim odnosima i rezultatima terenskog kartiranja, za potrebe ovog rada i kvalitetnije analize izdvojen je prostor gradskog centra Krapine (slika 7). On je definiran između Ulice Ante Starčevića - Trga Stjepana Radića - Ulice Ljudevita Gaja - Trga Ljudevita Gaja - Magistratske ulice - Ulice Dragutina Gorjanovića Krambergera Celjske ceste - Ulice Ivana Rendića. Površina izdvojenog gradskog centra iznosi približno $0,45 \mathrm{~km}^{2}$. 
Slika 7.

Razmještaj objekata u izdvojenog gradskom centru Krapine

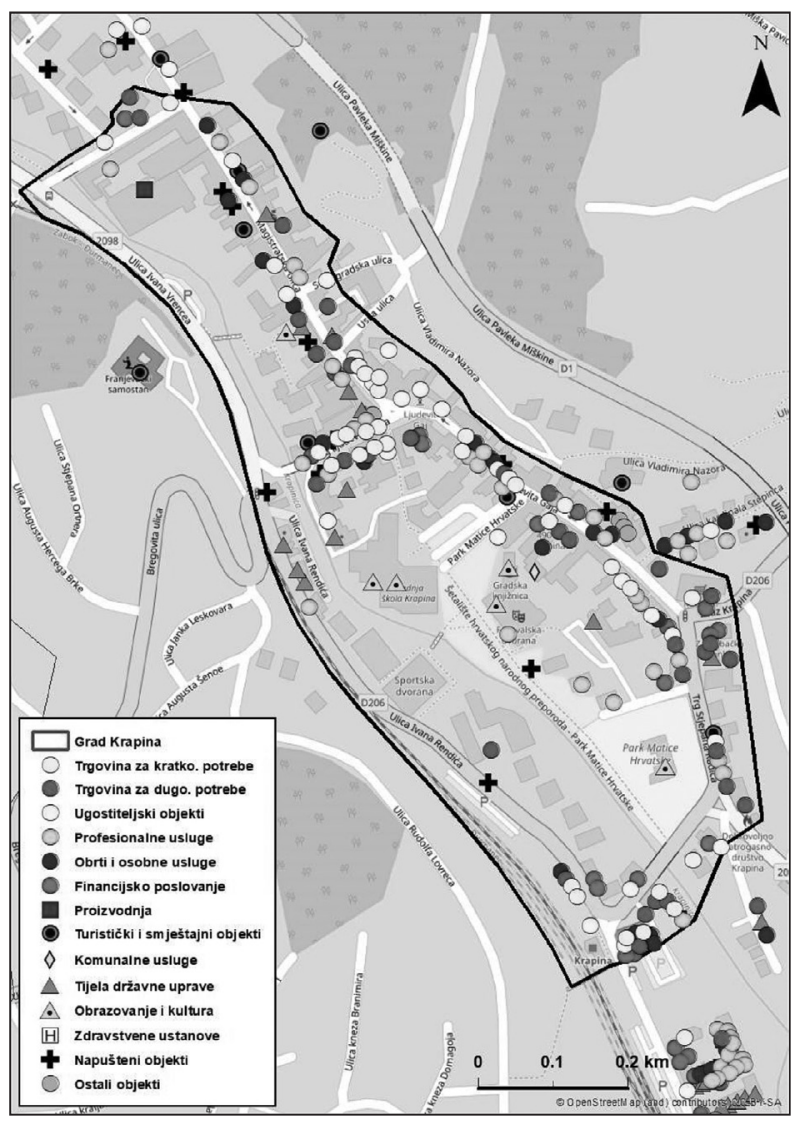

Izvor: izradili autori

U Ulici Ivana Rendića manja je koncentracija objekata nego u ostalim ulicama i trgovima izdvojenog gradskog centra (slika 7). To je, međutim, ulica koja u svojem južnijem dijelu ima vrlo izraženu stambenu funkciju te također prostornom logikom pripada gradskom centru i vrlo je bitna za njegovu prostornu organizaciju. Uz navedenu stambenu funkciju, prisutna su i tijela državne uprave te dva objekta financijskog poslovanja. Ta ulica ima vrlo bitnu ulogu u organizaciji prometa u gradu jer se u njoj nalaze dva najveća parkirališta u i oko gradskog centra te je njome također najjednostavnije osobnim automobilima i vozilima javnog gradskog prijevoza izaći iz gradskog centra. Na nju se u smjeru juga veže Ulica Frana Galovića - ulica s najvećim brojem kartiranih objekata.

Funkcije u tom prostoru privlače stanovništvo grada i regije te omogućuju brojne interakcije. Takve su funkcije npr. uprava, poslovanje, trgovina, ugostiteljstvo, kultura, obrazovanje, zabava i usluge (Maretić, 1996.). Zahtjevi za lokaciju tercijarnih djelatnosti razlikuju se od zahtjeva za lokaciju industrije. Za tercijarne djelatnosti je 
to što veća dostupnost stanovništva (Vresk, 1990.). Očekivano je stoga kako je i u Krapini glavnina tercijarnih djelatnosti koncentrirana upravo u gradskom centru i u njegovoj neposrednoj blizini. Terenskim kartiranjem utvrđeno je da je koncentracija poslovnih i upravnih funkcija u Krapini logično najveća u najfrekventnijim ulicama gradskog centra te također u ulicama koje iz njega „izlaze“. Primjeri su Ulica Frana Galovića, Ulica Dragutina Domjanića, Zagrebačka cesta, Ulica Kardinala Stepinca i Ulica Matije Gupca.

Različitošću i brojem objekata unutar tog prostora danas prednjači Ulica Ljudevita Gaja. Kao specifičnost Gajeve ulice početkom 20. st. javlja se diferencijacija po namjeni između njezine istočne i zapadne strane. Istočna strana, koja je ranije izgrađena, ima stambenu namjenu, a na zapadnoj, zbog blizine Krapinčice kao izvora energije (mlinovi), nastaju manufakture. Kasnije su tu smješteni i različiti novčarski zavodi. Magistratska ulica, nekadašnja srednjovjekovna jezgra, potpuno se izgrađuje kontinuiranom frontom pročelja. Ta ulica gubi funkciju gradskog središta, no zadržava rezidencijalnu i upravnu ulogu (Vučetić, 2004.). Magistratska ulica danas ima vrlo izraženu upravnu funkciju jer su u njoj locirani Gradska uprava, Matični ured Krapina, sjedište Krapinsko-zagorske županije, Turistička zajednica Krapinsko-zagorske županije i Državna geodetska uprava.

Zbog svoje funkcionalne snage gradski se centar sa sociološkog aspekta često prikazuje kao mjesto susreta ljudi i interakcije raznih gradskih funkcija (Maretić, 1996.). Iz tog razloga ne iznenađuje i najveća koncentracija ugostiteljskih objekata u njima, u svrhu društvenog okupljanja. Tako se primjerice u gradskom centru Krapine nalaze čak 23 ugostiteljska objekta, što je 45 \% njihovog ukupnog broja.

Na temelju navedenog može se zaključiti da u tom funkcionalno najvažnijem (najheterogenijem) dijelu Grada postoje brojne funkcije, ali one uglavnom pripadaju kategoriji klasičnih tercijarnih djelatnosti (usluge), dok nedostaju one koje bi generirale daljnji rast i razvoj. Pri tome se misli na jačanje financijskih, profesionalnih, znanstvenih i kulturnih usluga i institucija (Lončar, 2017.). Najvećim dijelom nedostatak tih poslovnih djelatnosti posljedica je blizine Zagreba, kojem Krapina gravitira.

Južni dio prostora obuhvaća najveći broj naselja i najveću površinu od triju prethodno izdvojenih dijelova. Naselja koja obuhvaća taj dio grada Krapine su: Polje Krapinsko, Pretkovec, Vidovec Krapinski, Pristava Krapinska, Vidovec Petrovski, Velika Ves, Lepajci, Gornja Pačetina, Škarićevo i Donja Šemnica. Ukupna mu je površina $28,78 \mathrm{~km}^{2}$ (što je 60,5 \% ukupne površine Grada). U njima je evidentirano 59 objekata s poslovnim i/ili upravnim funkcijama te još tri napuštena objekta.

Zbog skučenog položaja u kotlini, Krapina se iz gradske jezgre prvotno brže širila prema bližim prostorima na sjeveru, gdje je formirana stara industrijska zona zbog blizine ugljenokopa i kamenoloma. Danas je zbog više slobodnog prostora prostorno širenje usmjereno na reljefno proširenje doline Krapinčice prema jugu. Planiranje tog prostora intenziviralo se 1970-ih i 1980-ih godina i u tadašnjim je prostorno-planskim dokumentima tu planirana najintenzivnija izgradnja i proširivanje industrijskokomunalne zone. 
Slika 8.

Razmještaj objekata na južnom dijelu istraživanog prostora

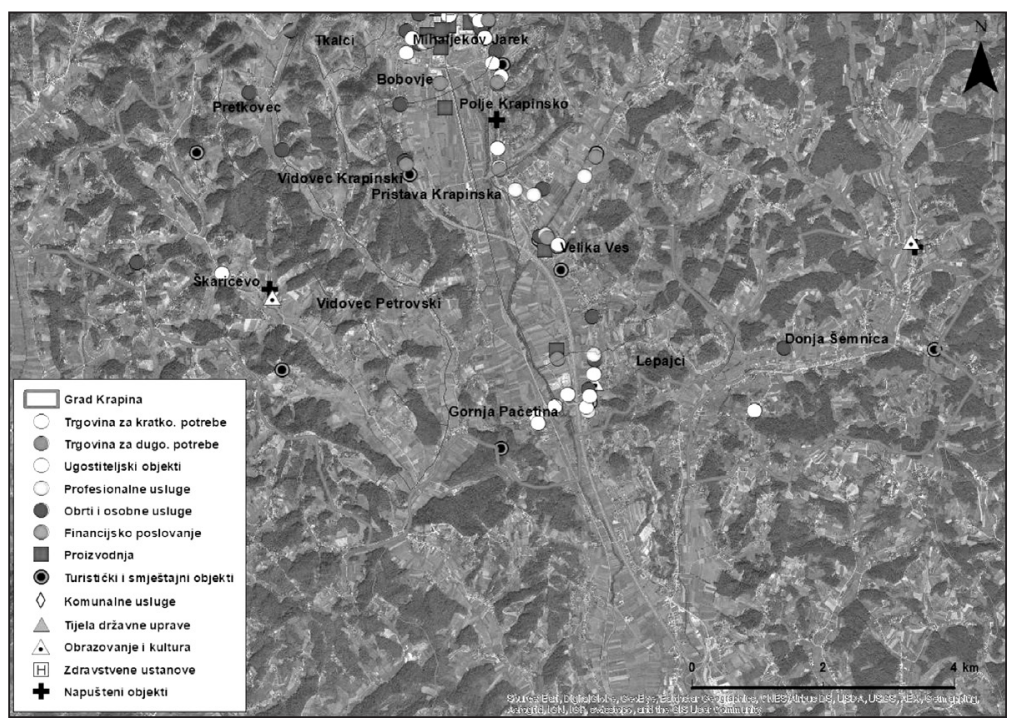

Izvor: izradili autori

Ne iznenađuje stoga kako je to prostor u kojem se od početka 21. stoljeća događaju najočitije promjene. Naselja južno od gradske jezgre, u kojima je započelo prvo širenje grada prema jugu, su centru najbliži Bobovje, Mihaljekov Jarek i Polje Krapinsko. Sva su tri navedena naselja prema broju objekata, poslije naselja Krapine, funkcionalno najopremljenija i najdiverzificiranija. Glavnina njih nalazi se uz državnu cestu (D1) sve do naselja Velika Ves, nakon čega se koncentriraju uz glavnu pristupnu cestu koja se na nju nastavlja prema naselju Krapini i ulazi u gradski centar kao Zagrebačka cesta. Navedene prometnice prolaze kroz naselja Lepajci, Velika Ves i Polje Krapinsko 9 te se na prostoru do 200 metara oko njih nalaze 32 objekta. Funkcionalna važnost prostora uz prometnicu ogleda se u podatku da je u navedenim trima naseljima ukupno 40 objekata, što znači da je uz tu prometnicu locirano 80 \% objekata s poslovnim funkcijama.

Iako se tu trenutno nalaze samo tri proizvodna objekta, to je prostor na kojemu je prema prostorno-planskim dokumentima predviđena značajna proizvodna uloga jer se u njemu nalazi veći dio Poduzetničke zone Krapina Nova.

9 Kasnije prolaskom kroz naselje Mihaljekov Jarek pod nazivom Zagrebačka cesta ulazi u gradski centar, odnosno nastavlja se kroz gradski centar kao Ulica Ljudevita Gaja. 


\section{Anketno istraživanje}

Nakon što je terenskim kartiranjem utvrđen prostorni razmještaj objekata s poslovnim/upravnim funkcijama, kao metoda za utvrđivanje razine zadovoljstva lokalnog stanovništva dostupnošću sadržaja i funkcija u Gradu Krapini odabrano je anketno istraživanje. Budući da je dostupnost pojedinih usluga jedan od ključnih faktora u valorizaciji urbanog prostora i posljedično vrlo bitan aspekt kvalitete života, u anketnom istraživanju naglasak je stavljen upravo na doživljaj i procjenu razine zadovoljstva lokalnog stanovništva dostupnošću pojedinih usluga.

Povećana prisutnost pojedinih poslovnih i naročito proizvodnih objekata, uz pozitivne učinke, također može i negativno utjecati na kvalitetu života na nekom prostoru. ${ }^{10}$ Iz navedenog razloga anketnim istraživanjem nastojala se utvrditi razina zadovoljstva kvalitetom okoliša, stanovanjem i osjećajem sigurnosti. S obzirom na vrstu postavljenih pitanja, rezultati anketnog istraživanja doprinose sagledavanju dosad neistražene kvalitete života u Gradu Krapini te razlika između urbaniziranog središnjeg naselja i ostalih pretežno ruralnih naselja. Potencijalno utvrđene razlike vrlo su bitne prilikom planiranja budućeg razvoja. Sudjelovanje javnosti u istraživanjima kvalitete života također donosi vrijednu povratnu informaciju o efikasnosti javnih usluga, obrascima kretanja, korištenju raznih objekata i usluga te općenito o mišljenjima i pitanjima poput sigurnosti, dostupnosti, participacije u radu lokalne zajednice i sl. (Slavuj, 2012.a).

„Kvalitetu života kao koncept čine brojne sastavnice ili elementi koji su indikatori određene razine stanovanja, obrazovanja, uvjeta rada, zdravlja, odmora i rekreacije (slobodnog vremena) te prehrane" (Svirčić Gotovac, 2006.). Ona se definira kao stupanj zadovoljstva postojećom životnom situacijom pojedinca ili grupe, i to kroz zadovoljstvo osnovnim ljudskim potrebama, zatim razvijenim potrebama ili onim ekskluzivističkim (specijaliziranim). Kvaliteta života je „situacija, egzistencijalno stanje manje ili veće (ne)zadovoljenosti potreba pojedinca, odnosno potreba različitih grupnih entiteta kao što su: slojevi, klase, profesionalne grupe i sl." (Lay, 1991., preuzeto iz Svirčić Gotovac, 2006.).

Kvaliteta života danas je visoko na listi prioriteta gradskih uprava te je u svijetu pokrenut niz projekata i programa usmjerenih na poboljšanje života u gradovima.

10 U smislu česte nepoželjnosti ponajprije proizvodnih objekata od strane lokalnog stanovništva, zbog povećanja ljudi i prometa na nekom prostoru, odnosno posljedičnog potencijalnog zagađivanja okoliša, povećanja buke i sl. dimenzija društva (ekonomske, socijalne, kulturne, političke), kao i prirodnog okoliša. U istraživanju tog konstrukta prožimaju se faktori odnosa čovjek - okoliš, prostorne organizacije, diferencijacije i klasifikacije prostora do općenito zanimanja kako te je povezan s urbanim planiranjem, održivim razvojem, jednakošću i socijalnom kohezijom (Slavuj, 2012.b).

Geografske studije kvalitete života također su složene jer uključuju elemente različitih Koncept se pojavljuje kao ključni pojam u temeljnim dokumentima razvoja grada 
se i zašto jedan prostor razlikuje od drugog (Smith, 1973., preuzeto iz Slavuj Borčić i Šakaja, 2017.). Geografska istraživanja kvalitete života stavljaju, dakle, naglasak na elemente kao što su razmještaj, dostupnost te preklapanje različitih prirodnih i društvenih fenomena u prostoru (Krevs, 1998., preuzeto iz Slavuj Borčić i Šakaja, 2017.).

U novije vrijeme pristupi temeljeni na statističkim analizama brojnih indikatora dopunjavaju se istraživanjem subjektivnih aspekata kvalitete življenja. Za njima se češće poseže pri istraživanju na nižim prostornim razinama, a kao metode koriste se intervjui, ankete i sl. Pacione (2005.) ističe kako za pravilno razumijevanje kvalitete življenja valja kombinirati subjektivne i objektivne aspekte kvalitete življenja, tj. „valja razmotriti stvarni grad u prostoru i mentalni grad u glavama ljudi“ (Lukić i dr., 2005.).

U ovom istraživanju, anketa je provedena na prigodnom uzorku (ukupno je 95 ispitanika anketu ispunilo metodom „lice u lice"), a ostatak anketnih upitnika je proširen metodom „snježne grude“11 putem emaila i Facebooka. Upitnik se odnosi na subjektivni doživljaj ispitanika te njihove stavove i procjene o kvaliteti života vezane uz pojedine funkcije u Gradu. Subjektivni pokazatelji naglašavaju individualnu percepciju i evaluaciju, te ukazuju do koje su razine ispunjena subjektivna očekivanja pojedinca. S druge strane, objektivni pokazatelji odražavaju objektivna stanja i promjene neovisno o osobnim evaluacijama (Slavuj, 2014.). Osnovna obilježja ispitanih građana nalaze se u tablici 1 , a odnose se na njihovu dob, starost te razinu obrazovanja.

Tablica 1.

Osnovna obilježja ispitanika prema spolu, dobi i statusu obrazovanja

\begin{tabular}{|c|c|c|}
\hline \multirow{2}{*}{$\begin{array}{l}\overrightarrow{0} \\
\text { ஸे }\end{array}$} & Muški & $61(46,2 \%)$ \\
\hline & Ženski & $71(53,8 \%)$ \\
\hline \multirow{4}{*}{ 음 } & $18-25$ & $23(17,4 \%)$ \\
\hline & $26-45$ & $54(40,9 \%)$ \\
\hline & $46-65$ & $31(23,5 \%)$ \\
\hline & Više od 65 & $24(18,2 \%)$ \\
\hline \multirow{6}{*}{ 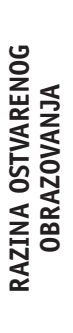 } & Bez škole & $1(0,8 \%)$ \\
\hline & Osnovna škola & $7(5,3 \%)$ \\
\hline & Srednja škola & $63(47,7 \%)$ \\
\hline & Viša škola, prvi stupanj fakulteta ili stručni studij & $29(22 \%)$ \\
\hline & Fakulteti, umjetničke akademije, sveučilišni studij & $30(22,7 \%)$ \\
\hline & Poslijediplomski studij (magisterij/doktorat) & $2(1,5 \%)$ \\
\hline
\end{tabular}

11 Metoda „snježne grude“ temelji se na početnom odabiru uskog kruga ljudi potrebnih karakteristika koji dalje sami šire uzorak, upućujući istraživača na osobe koje bi također mogao ispitati. 
U provedenom anketnom upitniku tražila se procjena ispitanika o dostupnosti određenih gradskih funkcija koje su bile kartirane, a kasnije i analizirane unutar rada. Dostupnost javnih usluga poput obrazovanja, zdravstvene zaštite, trgovine za svakodnevnu opskrbu ili sadržaja za rekreaciju, važna je za kvalitetan svakodnevni život. Može se pretpostaviti da što je bolja dostupnost i pokrivenost usluga i sadržaja to je i iskustvo kvalitete života pozitivnije. Pojedine društvene skupine poput starijih stanovnika, djece ili siromašnijih slojeva više ovise o resursima neposrednog prostora jer su obično manje mobilni i samostalni u kretanju gradom. Istraživanja su pokazala da dobra dostupnost umanjuje negativne aspekte kao što su primjerice nizak nivo individualnih resursa te time znatno povećava razinu kvalitete života (Slavuj, 2012.b.).

Za procjenu vlastitog zadovoljstva ispitanicama su ponuđene sljedeće funkcije u Gradu Krapini: poslovna - trgovina za kratkoročne potrebe, trgovina za dugoročne potrebe, obrta i osobnih usluga, objekata financijskog poslovanja; zdravstvena - kroz pružatelje zdravstvenih usluga; obrazovna - putem obrazovnih institucija; komunalna - kroz mjesta za odlaganje otpada i organizacije prometa u gradu; uslužna - putem ugostiteljskih objekata, profesionalnih usluga, sportskih i rekreacijskih sadržaja te ostalih - kvaliteta okoliša, kvaliteta stanovanja i osjećaj sigurnosti. Za procjenu korištene su Likertove skale u rasponu od 1 do 10 (1 označava izrazito nezadovoljstvo, 5 - niti zadovoljstvo niti nezadovoljstvo, a 10 izrazito zadovoljstvo).

S obzirom na navedeno, građani su se izjasnili kako su najzadovoljniji osjećajem sigurnosti. Ispitanici su je ocijenili prosječnom ocjenom 8,56. To je ujedno jedini izdvojeni aspekt života koji su ispitanici ocijenili ocjenom većom od 8. Ispitanici su također prosječnom ocjenom većom ili jednakom 7 ocijenili dostupnost trgovina za kratkoročne potrebe $(7,91)$, dostupnost objekata financijskog poslovanja $(7,73)$, kvalitetu stanovanja $(7,21)$ te dostupnost obrazovnih institucija $(7,0)$. Najnižom ocjenom ocijenjena je organizacija prometa u gradu, koja je obuhvatila promet u cjelini, od javnog prijevoza, prometne infrastrukture (stanje cesta, infrastrukture za biciklistički promet itd.) do prometa u mirovanju (npr. broja parkirališnih mjesta). Organizaciju prometa u gradu ispitanici su ocijenili prosječnom ocjenom 4,52. Nakon organizacije prometa ispitanici su najmanje zadovoljni dostupnošću trgovina za dugoročne potrebe (prosječna ocjena $=5,23$ ) i dostupnošću sportskih i rekreacijskih sadržaja (prosječna ocjena $=5,56$ ) 
Slika 9.

Zadovoljstvo ispitanika nekim elementima života u Gradu Krapini

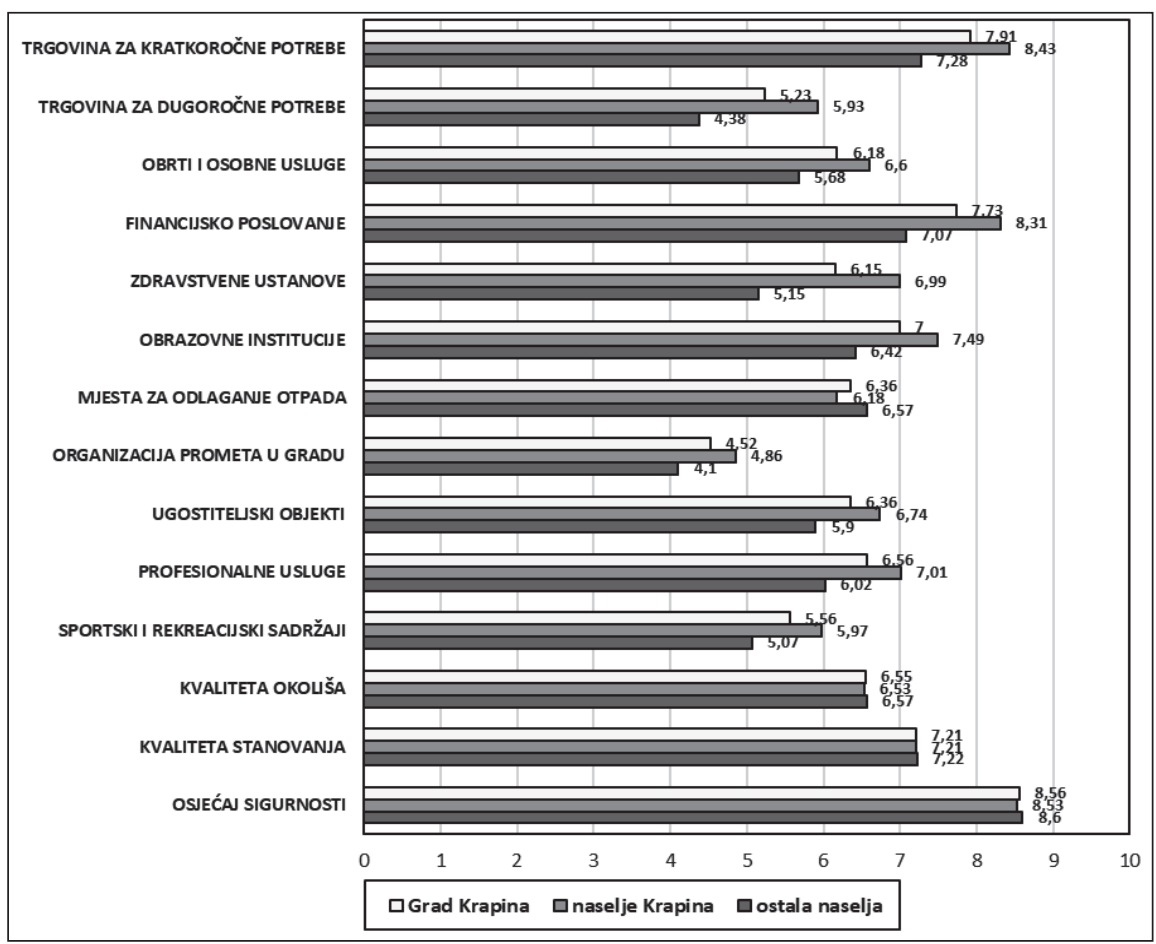

Uspoređujući razliku prosječnog zadovoljstva ispitanika u naselju Krapini i ostalih naselja, primjetno je kako su ispitanici iz naselja Krapine prosječno zadovoljniji od ostalih, iako ne značajnije. Prosječna ocjena svih istraživanih aspekata u naselju Krapini iznosi 6,91, dok za ostala naselja iznosi 6,15. Od ukupno 14 izdvojenih elemenata života, u samo su četirima slučajevima ispitanici iz ostalih naselja bili zadovoljniji u odnosu na one iz naselja Krapine. To se prvenstveno odnosi na dostupnost mjesta za odlaganje otpada, kvalitetu okoliša, kvalitetu stanovanja i osjećaj sigurnosti.

Analizom odgovora procjene zadovoljstva funkcionalnom opremljenošću i dostupnošću općenito se može zaključiti kako je stanovništvo naselja Krapine ukupno zadovoljnije dostupnošću pojedinih funkcija. Uspoređujući vrijednosti prosječnih ocjena koje nisu povezane s funkcionalnom opremljenošću, a to su kvaliteta okoliša, kvaliteta stanovanja i osjećaj sigurnosti, vidljivo je kako gotovo i nema razlika u zadovoljstvu njima između ispitanika iz naselja Krapine i ostalih naselja.

Najveće su razlike u zadovoljstvu između naselja Krapine i ostalih naselja primijećene kod dostupnosti pojedinih poslovnih funkcija. Takvi rezultati ujedno pokazuju kako je teorijski pretpostavljena povezanost subjektivnog doživljaja zadovoljstva aspektima života i funkcionalne opremljenosti naselja ostvarena na istraživanom prostoru. Najveće razlike u vrijednostima prosječnih ocjena zadovoljstva ispitanika, 
uspoređujući naselje Krapinu i ostala naselja, prisutne su kod tipičnih gradskih funkcija - zdravstva, obrazovanja, trgovine i financijskog poslovanja.

Najveća se razlika uočava u zadovoljstvu ispitanika dostupnošću pružatelja zdravstvenih usluga (za 1,84 veća kod naselja Krapine). Razlika veća od 1 prisutna je i kod dostupnosti trgovina za dugoročne potrebe (za 1,55 veća kod naselja Krapine), objekata financijskog poslovanja (za 1,24 veća kod naselja Krapina), trgovina za kratkoročne potrebe (za 1,15 veća kod naselja Krapine) te dostupnosti obrazovnih institucija (za 1,07 veća kod naselja Krapine).

\section{Zaključak}

U ovom radu cilj je bio prikazati detaljnu analizu funkcionalne strukture Grada Krapine kako bi se ustanovila njezina funkcionalna obilježja koja su posljedica prostornog širenja u zadnjih četrdesetak godina. Terenskim je kartiranjem utvrđeno da je središnji dio istraživanog prostora, u kojem se nalazi gradsko naselje, funkcionalno najopremljeniji. To je prostor s povoljnim fizičko-geografskim obilježjima koji je bio ishodište prostornog širenja. U okviru središnjeg dijela prostora u radu je posebno izdvojen i analiziran gradski centar, kao dio Grada s najvećom koncentracijom objekata s poslovnim i/ili upravnim funkcijama. S obzirom na to nameće se zaključak kako se udaljavanjem od centra broj poslovnih objekata smanjuje, a na to naročito utječe nepovoljna morfološka struktura Grada, koji se prostire u smjeru sjever - jug. Ujedno je očito da se idući od centralnog naselja prema ruralnijoj periferiji također smanjuje gustoća naseljenosti, što je bitno u planiranju buduće lokacije poslovnih objekata zbog blizine potencijalnih korisnika.

Analizirajući rezultate ankete, koja je trebala prikazati odnos stanovnika prema dostupnosti i kvaliteti, odnosno zadovoljstvo navedenim funkcijama, odgovori stanovnika Grada ukazuju da zadovoljstvo dostupnošću ispitivanih sadržaja također opada od centra prema periferiji, odnosno da je stanovništvo Krapine generalno zadovoljnije u odnosu na stanovništvo iz šire okolice, tj. ostalih rubni(ji)h naselja Grada. Građani su se također izjasnili kako su, od ponuđenih opcija, najzadovoljniji osjećajem sigurnosti. Ispitanici su je ocijenili prosječnom ocjenom 8,56, što je ujedno jedini aspekt života koji su ispitanici ocijenili ocjenom većom od 8. Najnižom ocjenom ocijenjena je organizacija prometa u gradu, koja je obuhvatila promet u cjelini, od javnog prijevoza, prometne infrastrukture do prometa u mirovanju (npr. broja parkirališnih mjesta).

Na kraju se može zaključiti da je Grad Krapina, iako županijski centar, prostorno i demografski ograničen, o čemu treba voditi računa u budućnosti prilikom planiranja aktivnosti koje bi bile nosioci lokalnog razvoja. Iako Grad ima određene poslovne funkcije, činjenica je također da neke važnije djelatnosti koje bi bile potencijalni generatori gospodarskog rasta te koje bi poticale jači profesionalni, stručni i znanstveni razvoj - nedostaju. 


\section{Literatura}

1. Biruš, M. (2000). Kulturne funkcije satelitskih naselja gradova Zagreba, Hrvatski geografski glasnik, 62 (1): 109-122.

2. Braičić, Z. i Džihić, E. (2015). Utjecaj urbanih funkcija Siska i Petrinje na transformaciju i gravitacijsku usmjerenost prigradskog naselja Mošćenica. Sociologija i prostor, 53 (3): 233-253.

3. Brezinščak Bagola; B., Cesarec, I. i Klemenčić, M. (Ur.) (2017). Krapina. Enciklopedija Hrvatskog zagorja. Zagreb: Leksikografski zavod Miroslav Krleža.

4. Državni zavod za statistiku. Popis stanovništva, kućanstava i stanova u Republici Hrvatskoj 2011. godine: Stanovništvo prema starosti i spolu po naseljima, www.dzs.hr (6.3.2019.).

5. Državni zavod za statistiku. Popis stanovništva, kućanstava i stanova u Republici Hrvatskoj 2011. godine: Zaposleni prema područjima djelatnosti, starosti $i$ spolu, www.dzs.hr. (15.11.2019.)

6. European Union (2012). Town - Small and Midium sized towns in their functional territorial context, 20113., Inception report, version 02/07/2012. https://www. espon.eu/sites/default/files/attachments/TOWN_Inception_report_July 2012. pdf (Pregledano 15.11.2019.)

7. FINA. https://www.fina.hr/-/u-2018-godini-poduzetnici-krapinsko-zagorske-zupanije-povecali-prihode-za-10-6-17. (Pregledano 14.11.2019.)

8. Generalni urbanistički plan Općine Krapina (1988). Zagreb: Urbanistički institut SR Hrvatske.

9. Gotovac, Svirčić, A. (2006). Kvaliteta stanovanja u mreži naselja Hrvatske. Sociologija sela, 171 (1): 105-126.

10. Gotovac, Svirčić, A. i Zlatar, J. (2007). Prehrana i zdravlje kao elementi kvalitete Života u mreži naselja Hrvatske. Sociologija i prostor, 45 (1): 29-60.

11. Gotovac, Svirčić, A. i Zlatar, J. (2015). Kvaliteta života u novostambenim naseljima i lokacijama u zagrebačkoj mreži naselja. Zagreb: Institut za društvena istaživanja u Zagrebu.

12. Hrvatska gospodarska komora, Broj $i$ struktura poslovnih subjekata po županijama - stanje 31.12.2017., veljača 2018., www.hgk.hr.

13. Klarić, Z. (2016). Funkcije sjedišta županije i prometne veze kao čimbenici privlačnosti glavnih urbanih središta Hrvatske. Geoadria, 21 (1): 29-57.

14. Klempić Bogadi, S.; Podgorelec, S. i Šabijan, M. (2016): Materijalno blagostanje kao objektivna dimenzija kvalitete života stanovništva ruralnih prostora - općina Gornja Rijeka. Sociologija i prostor, 54 (3): 197-21.

15. Lončar, J. (2017). Spatial structure od some business activities in the area of small and mid-size cities (periurban area) in the County of Zagreb. Analele Universitatii din Oradea, Seria Geografie, 2017 (2): 280-291.

16. Lukić, A.; Prelogović, V. i Pejnović, D. (2005). Suburbanizacija i kvaliteta življenja u zagrebačkom zelenom prstenu - primjer općine Bistra. Hrvatski geografski glasnik, 67 (82): 85-106.

17. Lukić, A. (2012). Mozaik izvan grada - tipologija ruralnih $i$ urbaniziranih naselja Hrvatske. Samobor: Meridijani.

18. Maretić, M. (1996). Gradski centri. Zagreb: Školska knjiga 
19. Le Nechet, F. (2012). Urban spatial structure, socio-economic indicators and mobility patters. European Journal of Geography. http://journals.openedition. org (Pregledano 14.11.2019).

20. Mirošević. L. i Jolić, J. (2015). Objektivni i subjektivni pokazatelji kvalitete životnog prostora grada Požege. Radovi Zavoda za znanstveni i umjetnički rad u Požegi, 4 (2015): 147-172.

21. Mostarac, K. i Feletar P. (2019). Primjena metode obuhvata područja za određivanje dostupnosti poštanskih ureda: primjer Bjelovarsko-bilogorske županije. Geoadria, 24 (1): 53-70.

22. Opačić, V. T.; Gašparović, S. i Dolenc, N. (2019). Analiza rekreacijske funkcije odabranih zelenih površina u Gradu Zagrebu - razlika u navikama posjetitelja. Geoadria, 24 (1): 23-51.

23. Pacione, M. (2005). Urban Geography: A Global Perspective, Routlegde, London.

24. Rišova, K. i Pouš, R. (2018). Urban facilities in the quality of life research: A case study of Banska Bystrica city (Central Slovakia). Geographical Review, 70 (2): 99-116.

25. Seferović, D. (2005). Piramidalna mreža gradova. Sociologija i prostor, 43 (3): 579-615.

26. Slavuj, L. (2012a). Evaluacija kvalitete urbanoga susjedstva - prednosti i nedostaci neposrednoga životnog prostora. Sociologija i prostor, 193 (2): 183-201.

27. Slavuj, L. (2012b). Kvaliteta života u odabranim susjedstvima Grada Rijeke. $\mathrm{Hr}$ vatski geografski glasnik, 74 (2): 69-88.

28. Slavuj, L. (2014). Problem određivanja složenijh (objektivnih i subjektivnih) indeksa kao cjelovitih mjera kvalitete života. Sociologija i prostor, 52 (1): 23-39.

29. Slavuj Borčić, L. (2017). Kvaliteta Života kao predmet geografskih istraživanja: osvrt na razvoj interesa i teorijskih modela istraživanja. Hrvatski geografski glasnik, 79 (1): 5-31.

30. Središnji registar prostornih jedinica. www.dgu.hr (6.3.2019.)

31. Vresk, M. (1986). Neki pokazatelji funkcionalno-prostorne strukture Zagreba. Acta Geograpfica Croatica, 21 (1): 45-53.

32. Vresk, M. (1990). Grad u regionalnom i urbanom planiranju. Zagreb: Školska knjiga.

33. Vresk, M. (1996). Funkcionalna struktura i funkcionalna klasifikacija gradova Hrvatske. Hrvatski geografski glasnik, 58 (1): 51-66.

34. Vresk, M. (2002). Grad i urbanizacija. Zagreb: Školska knjiga 
PRILOG: Anketni upitnik

1. Spol: $\quad M \quad \check{Z}$

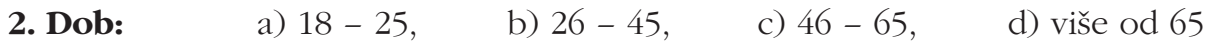

3. Stupanj obrazovanja: $\quad$ a) bez završene škole

b) osnovna škola

c) srednja škola

d) viša škola, prvi stupanj fakulteta (preddiplomski)

ili stručni studij

e) fakulteti, umjetničke akademije, sveučilišni studiji

f) poslijediplomski studij (magisterij znanosti/ doktorat)

4. Naselje stanovanja/prebivališta?

Ocjenom od 1 do 10 ocijenite (označavanjem jednog od kvadratića) koliko ste zadovoljni navedenim domenama života u gradu Krapini. (Dostupnost se smatra stupanjem na kojem ljudi pristupaju životnim aktivnostima u okviru prihvatljivih troškova, u razumnom vremenu is podnošljivom lakoćom).

5. Dostupnošću trgovina za kratkoročne potrebe (prehrambeni proizvodi, pekare, cvjećarnice...)

\begin{tabular}{|l|l|l|l|l|l|l|l|l|l|}
\hline 1 & 2 & 3 & 4 & 5 & 6 & 7 & 8 & 9 & 10 \\
\hline & & & & & & & & & \\
\hline
\end{tabular}

6. Dostupnošću trgovina za dugoročne potrebe (prodavaonice odjeće, obuće, namještaja, suvenira, tehničke robe, papirnice, knjižare, ljekarne i sl.)

\begin{tabular}{|l|l|l|l|l|l|l|l|l|l|}
\hline 1 & 2 & 3 & 4 & 5 & 6 & 7 & 8 & 9 & 10 \\
\hline & & & & & & & & & \\
\hline
\end{tabular}

7. Dostupnošću obrta i osobnih usluga (postolari, krojači, kozmetički saloni, frizeri, zlatari...)

\begin{tabular}{|l|l|l|l|l|l|l|l|l|l|}
\hline 1 & 2 & 3 & 4 & 5 & 6 & 7 & 8 & 9 & 10 \\
\hline & & & & & & & & & \\
\hline
\end{tabular}

8. Dostupnošću objekata financijskog poslovanja (banke, bankomati, pošta... )

\begin{tabular}{|l|l|l|l|l|l|l|l|l|l|}
\hline 1 & 2 & 3 & 4 & 5 & 6 & 7 & 8 & 9 & 10 \\
\hline & & & & & & & & & \\
\hline
\end{tabular}


9. Dostupnošću pružatelja zdravstvenih usluga (domovi zdravlja, ambulante...)

\begin{tabular}{|l|l|l|l|l|l|l|l|l|l|}
\hline 1 & 2 & 3 & 4 & 5 & 6 & 7 & 8 & 9 & 10 \\
\hline & & & & & & & & & \\
\hline
\end{tabular}

10. Dostupnošću obrazovnih institucija (dječji vrtići, osnovne škole, srednje škole, veleučilište...)

\begin{tabular}{|l|l|l|l|l|l|l|l|l|l|}
\hline 1 & 2 & 3 & 4 & 5 & 6 & 7 & 8 & 9 & 10 \\
\hline & & & & & & & & & \\
\hline
\end{tabular}

11. Dostupnošću mjesta za odlaganje otpada

\begin{tabular}{|l|l|l|l|l|l|l|l|l|l|}
\hline 1 & 2 & 3 & 4 & 5 & 6 & 7 & 8 & 9 & 10 \\
\hline & & & & & & & & & \\
\hline
\end{tabular}

12. Organizacijom prometa u gradu (javni promet, broj parkirališnih mjesta, stanje lokalnih cesta, biciklistička infrastruktura, kvaliteta pristupnih cesta itd.)

\begin{tabular}{|l|l|l|l|l|l|l|l|l|l|}
\hline 1 & 2 & 3 & 4 & 5 & 6 & 7 & 8 & 9 & 10 \\
\hline & & & & & & & & & \\
\hline
\end{tabular}

13. Dostupnošću ugostiteljskih objekata (restorani, kafići, slastičarnice i sl.)

\begin{tabular}{|l|l|l|l|l|l|l|l|l|l|}
\hline 1 & 2 & 3 & 4 & 5 & 6 & 7 & 8 & 9 & 10 \\
\hline & & & & & & & & & \\
\hline
\end{tabular}

14. Dostupnošću profesionalnih usluga (javni bilježnici, odvjetnički uredi, privatne liječničke i stomatološke ordinacije, optike, konzultantske tvrtke, softverske tvrtke i sl.)

\begin{tabular}{|l|l|l|l|l|l|l|l|l|l|}
\hline 1 & 2 & 3 & 4 & 5 & 6 & 7 & 8 & 9 & 10 \\
\hline & & & & & & & & & \\
\hline
\end{tabular}

15. Dostupnošću sportskih i rekreacijskih sadržaja

\begin{tabular}{|l|l|l|l|l|l|l|l|l|l|}
\hline 1 & 2 & 3 & 4 & 5 & 6 & 7 & 8 & 9 & 10 \\
\hline & & & & & & & & & \\
\hline
\end{tabular}

16. Kvalitetom okoliša

\begin{tabular}{|l|l|l|l|l|l|l|l|l|l|}
\hline 1 & 2 & 3 & 4 & 5 & 6 & 7 & 8 & 9 & 10 \\
\hline & & & & & & & & & \\
\hline
\end{tabular}




\section{Kvalitetom stanovanja}

\begin{tabular}{|l|l|l|l|l|l|l|l|l|l|}
\hline 1 & 2 & 3 & 4 & 5 & 6 & 7 & 8 & 9 & 10 \\
\hline & & & & & & & & & \\
\hline
\end{tabular}

\section{Osjećajem sigurnosti}

\begin{tabular}{|l|l|l|l|l|l|l|l|l|l|}
\hline 1 & 2 & 3 & 4 & 5 & 6 & 7 & 8 & 9 & 10 \\
\hline & & & & & & & & & \\
\hline
\end{tabular}


Prethodno priopćenje

Jelena Lončar

University of Zagreb, Faculty of Science, Department of Geography, Croatia

e-mail: jloncar@geog.pmf.hr

Ivan Sviben

University of Zagreb, Faculty of Science, Department of Geography, Croatia

e-mail: ivan.sviben@student.geog.pmf.hr

\title{
Contemporary Features of Functional-Spatial Structure of the City of Krapina
}

\begin{abstract}
Since no research that would clarify and deal with the issue of spatial and functional structure of the City of Krapina has been conducted until now, this paper analyses the functional characteristics of the City of Krapina, with an emphasis on its commercial and administrative activities, on the basis of the examination of spatial planning documents, the analysis of statistical data and fieldwork. In this way, a spatial database has been created, which serves as the basis for the research of the existing spatial structure of Krapina. Apart from the aforementioned methods, a survey focused on availability has also been conducted in order to find out the level of satisfaction with the immediate living space of the residents living in the area and to determine their satisfaction with certain aspects of life in the City of Krapina. The analysis of the survey responses determines the extent to which the local residents are satisfied with particular aspects of life in the City of Krapina.The survey was conducted on a total of 132 residents of the City of Krapina.
\end{abstract}

The results have shown that the functions of the City of Krapina are predominantly concentrated in the main settlement, which is a consequence of the structure of the analysed activities, together with natural features which limit the spatial development, such as relief characteristics that inhibit the dispersion of certain activities into the wider area, that is, the surrounding settlements.

Key words: City of Krapina, city functions, business activities, functional structure, spatial spreading, survey, quality of life. 